\title{
Environmental Sustainability and Human Resource Management Initiatives
}

\author{
Dr. Poornima S. C.
}

The bottom line of sustainability is the economic, environmental and social performance of an organization. Among the three it is quite evident to see organizations focusing on the economic aspect with more rigors to increase economic performance. It is but obvious for organizations to maximize their profits rationally to help them carry on their operations without the threat of solvency. Environmental performance of any organization is seen on two fronts. Either on a voluntary basis or as an impact of policy, fee levied by Government agencies or regulatory boards.

Citizens are now aware of issues of environmental performance, thereby voluntary organizations, and forums' of environmentalist influence organizations to abide by the rule and also show initiatives of being environmentally sensitized. The most commonly used measures are to levy a Hefty fine on high level of emissions and incentive of subsidies on lower level of emissions. The focus is on emissions being a reactive action to the program of environmental performance, but, the shift had to be pro-active looking into the energy reductions as an opportunity of performance. During the past two decades, a worldwide consensus has been emerged around the need for proactive environmental management goals. The responses from organizations are seen to be involving strategic decisions and behavior modification for organizations cmployees. It is not only the management but also the employees who are benefited by the green practices in the organizations.

The paper would like to analyze the initiatives taken by the organizations towards environmental performance for sustainability. The study uses stratified sampling technique and has a sample of 66 organizations located in Bangalore. The data examines the human resource initiatives implemented by the organizations as understood by the employees of the organization.

Key Words: Environmental sustainability, human resource initiatives, behavior modification, strategic decisions.

\section{Introduction}

The present day organizations are in the race to attract and retain their employees, who seek a meaning in their work. One way of ensuring "meaning to work" is to ensure their job contributes to the world and to human $\mathrm{kind} / \mathrm{planet}$ at large as well. One possible way of doing this is to contribute environmentally by adopting initiatives at the work place that showcases the organizational commitment to environmental sustainability. While such commitment differentiates the organization it can also serve as an advantage to attract and retain the generation $Y$ employees. These initiatives towards environmental sustainability is popularly termed as "Green Practices" which finds expression in telecommuting, flexible work schedules, reduced work weeks, incentives for alternative methods of

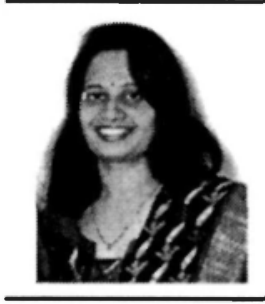

Dr. Poornima S. C.

Coordinator, Department of Studies in Commerce

BMS College for Women

Bangalore

email:poornimaresearch@yahoo.com 
transportation, awards for reduced energy use, implementing recycling programs, purchase of environmentally friendly office products.

Green practices are found to be effective in creating a positive corporate culture and has favorable impact on the work environment in organizations. It is equally important that an organization, while working towards setting a green work environment, has to secure commitments at all levels. It starts from the grass root level and stretches to the upper levels and also involves the outside contractors and product suppliers. An individual, who understands and believes the value system encouraged by the organizations, naturally starts appreciating and internalizing its beliefs as his own. This behavior calls for an extra-role to be played by an employee. Thus, the organizations explicit commitment to green practices automatically drives individual employee into a green behavior.

\section{Green behavior in organizations:}

In today's fast paced world, companies are moving for more competitive advantage for their survival and success. Having realized that green behavior or commitment to environmental sustainability is a differentiator in the marketplace, several organizations are concerned about global warming issues and wastage of resources. They have devised new methods of management of resources. These efforts of the organizations are channelized through the HR initiatives popularly termed as "Green Human Resource Management". To illustrate, Google switch on 1.6 megawatts of solar photovoltaic panels system at its head quarters in Mountain View, California, which was the largest corporate solar installation in the country. Managing resources in an environment responsible way has even attracted the attention of policy makers world wide.(Woodward, (2008) lan Pearson, who was the Minister of state for Climate Change and Environment for Great Britain, in May 2007, in his address at the United Nations $15^{\text {th }}$ Session of Commission on Sustainable Development, strongly advocates that a company's carbon statement will be prominent as its financial statements in the future( Manikas, Godfrey, (2010) While it is observed that organizations take a piecemeal approach to such initiatives, it is appreciable that environmental sustainability is increasingly and is positively considered by organizations. So much so, a new breed of leaders are now emerging in the human resource function called the "sustainability officers" and their team performs functions including public relations, environmental health and safety, risk management and energy conservations.

There are a lot of corporate houses doing their share of green initiatives. Vancity Credit Union encourages their employees to buy from green and socially conscious retailers when they shop for corporate gifts. BLC's gives an annual Evergreen Award to recognize the environmental initiatives taken by its employees. It has also linked the managers' energy saving initiatives to their annual bonus to create an extra push towards green initiatives. ISL engineering and Land Sercies took similar approach of allowing its green minded employees whom they term as green champions to devote $10 \%$ of their time researching environmental related projects and networking with other green business ventures.(Engelhart, Katie, (2010)) In fact, the globally renowned retail house Wal-Mart's has a strategic goal which reads "to be supplied 100 percent by renewable energy, creating zero waste and selling products that sustain people 
and the environment."(Bill Roth (2010))A survey of 93 organizations in United States, The Buck Consultants one of the world's leading human resource consulting firms, has found that $54 \%$ of them incorporate environmental management into their business operations. According to the survey the green initiatives used in workforce management and human resources practices are either strategic business plans or off hand practices. (www.bucksurveys.com ) While this being the experience of many of the MNC's mostly based in US, the following aims to document the green initiatives among Indian Companies.

In several organisations Green human resource management has gained a place in the board room to frame strategic decisions. Companies like Accenture follows the arrangement of telepresence or Video-conferencing as it helps in cutting cost and also indirectly contributes to the green initiative of the organization. Flexplace or Tele-commuting also reduces the cost of operation on the employer front and reduces the cost of transportation on the employee front. (Sinha (2010))

Organizations that are serious about incorporating green practices have also created environmental managernent systems. On an average it is seen that among organizations in India, especially the technology driven organizations, like IT, ITES, Banking and financial services, are the ones that have created a mark in the green space. Hardware and software development companies like WIPRO, HP, Mahindra Satyam, Cognizant etc., practice initiatives ranging from flexi time, telecommuting, electronic communication to introducing CFL or LED lighting systems and use of laptops to contribute to the green work place. The Mumbai based Patni Computers has recently setup a GREEN IT Center in Noida initiating green practices in hardware procurement, creating paper less organization data management systems and training systems.(Patni annual report,(2009)

\section{Review of Literature:}

Study conducted by Melvilli (2010) talks about developing a research agenda on information systems innovation for environmental sustainability that demonstrates the critical role that IS can play in shaping beliefs and enabling and transforming sustainable processes and practices in organizations. Smith and Sharicz (2011) in the action research conducted to assess the extent, to which organizations need to shift towards triple bottom line sustainability, recommend to organizations a shift from a quick fix approach to a well defined sustainability initiative. A cohesive, sustainability, and guidelines for implementation are also proposed in the research paper. Cavalcanti Sa de Abrev (2008) defines environmental policy to improve corporate sustainability in developing countries. The researcher demonstrates that environmental regulation and enforcement, environmental risk and demands from stakeholders play a role in increasing the corporate commitment to the natural environment. Scott Marshall.R., Brown and Darrell (2003) presents a systems perspective on environmental initiatives. The authors recommend the adoption of a commonly shared corporate vision to allow for clear direction in decision making. Rimonoczy, Isabel, Pearson and Tony (2010) reviews the environmental and social challenges that give rise to sustainability efforts and outline the areas of potential benefits to an organization. Singh Mitrabinda (2010) provides an insight of Indian business sustainability in the era of globalization through an analysis of economic 
performance of three Indian corporations while they are investing towards environmental sustainability.

While the above mentioned studies have document environmental sustainability practices there are a few studies how such practices are incorporated into human resource practices. Daily; Bonnie F; Su-chun Huang (2001) identify the human resource factors such as environmental training, employee empowerment, reward systems, top management support and teamwork as key elements of the implementation process of environmental management systems of an organization. Tim Sanders (2009) discuss how human resource operations can be carried on with the lowest impact and yet retain quality of service. It includes building, travel and transportation and documents. Boiral (2009) discusses how the principal dimensions of the organizational citizenship behaviors can be applied to environmental practices of organizations and underlines their importance in responding to essential challenges of environmental management.

Most of the studies reviewed are found to have taken a normative approach highlighted the desirability of having environmental sustainability practices while a few studies have recommended what should constitute environmental sustainability practices. A few have illustrated how some of them could be effectively incorporated into human resource functions.

\section{Research Methodology:}

There is a pronounced existence of green human resource initiatives seen all over the world which initiated the researcher to take stock of its footsteps in India. India being a developing country is in the race to make a mark in the corporate map of the world. Bangalore is a city that has contributed to the corporate map through its service sector.

The paper attempts to explore the existence of green human resource practices in organizations located in Bangalore. The primary objective of this paper is to examine the green human resource practices from the stage of human resource planning to exit interviews. The paper takes a sample of 66 organizations to study prevailing green human resource practices. The data was collected through an interview copy. A stratified sampling technique was used to select an equal representation of organizations from different sectors. The sectors were divided into three namely manufacturing, banking and other services, IT and ITes sector. In order to understand the green human resource practices that can impact individual's behavior and is a practice followed in the organizations a sample of $\mathbf{4 6}$ employees from the respondent organizations were selected on the basis of their willingness to participate in the survey and were personally interviewed.

Suitable statistical tools were used to analyze the data collected from both the corporate respondents and individual employees.

\section{Green initiatives practiced in the respondent organizations:}

The personal interview conducted by the researcher reveals the following as the green initiatives practiced by respondent organizations that the respondents believe to create an impact on the individual behavior.

Green Job description: The job description is used to specify environmental aspects that include health and safety tasks reporting about emissions at their capacities, special 
competencies relating to a green approach.

Selection: Green behavior analysis in the selection process of companies.

Induction: Induction or orientation program for new recruits to ensure that the new recruits understand and approach their corporate environmental culture.

Performance management system: Using environmental management and measuring performance standards. Performance standards cover the aspect of waste management, environmental audits and conservation of energy.

Communication systems: It explores the use of green communication systems and speaks about the extent of adaptation by employees.

Targets: Including green targets in the roles and responsibilities and appraisals of employees.

Appraisals: Performance appraisals predominantly evaluating the green practices adapted to accomplish the performance standards.

Penalty: The levy of fines and penalties for green targets not reached or green practices notfollowed.

Monetary: The practice of rewarding monetarily for the approach adapted by the employees towards accomplishing the green targets or following the green practices.

Training in environmental management: Organizations conduct training sessions relating to waste management, transport and air emissions, discussions relating to risk management and treatment of waste.

Development: The managerial development initiated by organizations relating to equipping their managers as environmental professionals.

Employee Involvement: Organizations inculcating methods of involving employees in their environmental management issues by participative management.

Quality circles: Creating problem solving circles for accomplishing green targets through quality circles of the organization.

Trade Unions: Unions being sensitive towards green issues and negotiating green workplace arrangements.

Non-monetary: Awarding compliant employees with rewards and recognition in open forms to encourage green behavior.

Exit Interviews: seeking information about the perception about employees regarding the green initiatives of the organization.

Socialization: creating forms for sensitizing employees in the issues of environmental protection and effective utilization.

Promotions: Including green behavior indicators in the promotion policy of the organization.

Whistle Blowing: Organizations laying protective policies for whistle blowers relating to environmental protection practices.

\section{Findings and Discussions:}

The Human resource strategies adopted and practices followed differ from one organization to another. Organizations predominantly comply with the standard practices that the sector adopts. Thus, the research paper captures the demographic details of the respondent organizations on the component of sector and age of the organization. 
Table3 - Percentage of respondent organizations practicing Green HR Initiatives: Table 1 - Distribution of sample organisations by sector:

\begin{tabular}{|l|c|c|}
\hline SECTOR & Frequency & Percent \\
\hline manufacturing & 22 & 33.3 \\
\hline IT\& ITES & 23 & 34.8 \\
\hline Banking \& Other services & 21 & 31.8 \\
\hline Total & 66 & 100.0 \\
\hline
\end{tabular}

As shown in table 1 the respondent organisations belong to three sectors manufacturing, IT \& ITES and Banking and Other services.

The age of an organization predominantly reflects the maturity of its human resource practices. Table 2 shows the distribution of respondent organisations based on the age.

Table 2 - Distribution of sample organization by age

\begin{tabular}{|l|c|c|}
\hline Interval & Frequency & Percent \\
\hline Less than 6 years & 0 & 0 \\
\hline between 6 and 11years & 24 & 36.4 \\
\hline 12 to 17years & 11 & 16.6 \\
\hline above 18 years & 31 & 47.0 \\
\hline Total & 66 & 100.0 \\
\hline
\end{tabular}

The table 2 shows that $47 \%$ of the respondent organisations have more than 18years of existence and $36.4 \%$ of the respondent organisations belong to 6 to 11 years of existence. $16.6 \%$ of them have 12 to 17 years of existence.

Majority of the organisations have more than 18 years of existence.

\section{Green Human Resource Practices:}

The human resource practices listed were covering a wide gamut of green interventions from human resource planning, job description, workers participation in management, employee involvement, exit interviews and legal interventions, etc.,. Table 3 depicts the distribution of respondent organization based on the green human resource initiatives practiced by them. A percentage analysis is used to make an analysis of the profoundly used green initiative.

\begin{tabular}{|l|l|l|l|l|l|}
\hline $\begin{array}{l}\text { Sl. } \\
\text { No }\end{array}$ & Green HR Practices & $\begin{array}{l}\text { Present/ } \\
\text { N=66 }\end{array}$ & $\begin{array}{l}\text { Sl. } \\
\text { No }\end{array}$ & Green HR Practices & $\begin{array}{l}\text { Present } \\
\text { / N=66 }\end{array}$ \\
\hline 1 & Job Description & $69.7 \%$ & 11 & $\begin{array}{l}\text { Training in Environmental } \\
\text { Management }\end{array}$ & $\mathbf{8 0 . 3 \%}$ \\
\hline 2 & Selection & $45.5 \%$ & 12 & Development & $45.5 \%$ \\
\hline 3 & Induction & $56.1 \%$ & 13 & Socialization & $63.6 \%$ \\
\hline 4 & $\begin{array}{l}\text { Performance } \\
\text { Management System }\end{array}$ & $51.5 \%$ & 14 & Whistle Blowing & $15.2 \%$ \\
\hline 5 & Communication Systems & $69.7 \%$ & 15 & Employee Involvement & $\mathbf{7 2 . 7 \%}$ \\
\hline 6 & Targets & $59.1 \%$ & 16 & Quality Circles & $53.0 \%$ \\
\hline 7 & Appraisals & $22.7 \%$ & 17 & Trade Union & $24.2 \%$ \\
\hline 8 & Penalty & $24.2 \%$ & 18 & Non-Monetary & $42.4 \%$ \\
\hline 9 & Monetary & $19.7 \%$ & 19 & Exit Interviews & $12.1 \%$ \\
\hline 10 & Promotions & $27.3 \%$ & & & \\
\hline
\end{tabular}


Table 3 shows that $80 \%$ of the respondent organizations are providing training to employees relating to environmental management practices Green human resource practices like employee involvement, green goals in the job descriptions, communication of environmental management initiatives across all levels of employees in the organization are practiced by more than $60 \%$ of the respondent organizations.

Observation towards the flip side of the practices not commonly followed by the respondent organizations show that $\mathbf{8 7 . 9 \%}$ of the respondent organizations do not try to understand through exit interview if an employee is leaving because of non-green initiatives or disagreeing with the non-green organization practices. $\mathbf{8 4 . 8 \%}$ of the respondent organizations do not have legal protection to whistle blowers relating to nongreen practices of the organization. $80 \%$ of the respondent organizations do not provide monetary rewards for green initiatives taken by employees at the work place.

From the above observations of green human resource practices followed in respondent organizations Table 4 takes only those practices that are followed by more than $60 \%$ of the organizations for a detail analysis on a moderating factor of age of the organizations.

Table 4 - Two way distribution of respondent organizations by Green HR and age:

\begin{tabular}{|l|lc|ll|lr|}
\hline $\begin{array}{l}\text { Human Resource } \\
\text { Practices/Existence }\end{array}$ & \multicolumn{2}{|l|}{$\begin{array}{l}\text { Between 6-11 years } \\
\text { Present N=24 }\end{array}$} & \multicolumn{2}{|l|}{$\begin{array}{l}12 \text { to } 17 \text { years } \\
\text { Present N=11 }\end{array}$} & \multicolumn{2}{|l|}{$\begin{array}{l}\text { Above 18 years } \\
\text { Present N=31 }\end{array}$} \\
\hline Job Description & 10 & $(41.67 \%)$ & 10 & $(90.9 \%)$ & 26 & $(83.87 \%)$ \\
\hline Communication Systems & 12 & $(50 \%)$ & 8 & $(72.7 \%)$ & 26 & $(83.87 \%)$ \\
\hline Socialization & 11 & $(45.83 \%)$ & 8 & $(72.7 \%)$ & 23 & $(74.19 \%)$ \\
\hline $\begin{array}{l}\text { Training in environmental } \\
\text { management }\end{array}$ & 19 & $(79.16 \%)$ & 8 & $(72.7 \%)$ & 26 & $(83.87 \%$ \\
\hline Employee Involvement & 10 & $(41.67 \%)$ & 10 & $(90.9 \%)$ & 28 & $(90.32 \%)$ \\
\hline
\end{tabular}

Note: Green HR Practices followed by more than $60 \%$ of the respondent organizations

The above table shows that $90 \%$ of the respondent organizations which have existence of 12 to 17 years and above 18 years have employee involvement and participation practices in their organizations. $83.8 \%$ of the respondent organizations follow the practice of having green job descriptions, green communication systems and training in environmental management issues. $79 \%$ Organizations that are existent since 6 to 11 years practice training in environmental management. Among other practices $90 \%$ of the organizations that have 12 to 17 years of existence have listed green goals in their job descriptions.

Further an analysis of the green human resource initiatives followed by more than $60 \%$ of the respondent organizations on the basis of the sector to which they belong is done in Table 5. 
Table 5 - Two way distribution of Green HR Practices and Sector:

\begin{tabular}{|l|lc|ll|ll|}
\hline $\begin{array}{l}\text { Human Resource } \\
\text { Practices/Sector }\end{array}$ & $\begin{array}{l}\text { Manufacturing } \\
\text { Present N=22 }\end{array}$ & \multicolumn{2}{l|}{$\begin{array}{l}\text { IT \& ITES } \\
\text { Present N=23 }\end{array}$} & \multicolumn{2}{l|}{$\begin{array}{l}\text { Banking \& other } \\
\text { Services } \\
\text { Present N=21 }\end{array}$} \\
\hline Job Description & 6 & $(27.27 \%)$ & 17 & $(73.91 \%)$ & 17 & $(80.95 \%)$ \\
\hline Communication Systems & 5 & $(22.72 \%)$ & 21 & $(91.30 \%)$ & 14 & $(66.66 \%)$ \\
\hline Socialization & 11 & $(50 \%)$ & 17 & $(73.91 \%)$ & 14 & $(66.66 \%)$ \\
\hline $\begin{array}{l}\text { Training in environmental } \\
\text { management }\end{array}$ & 21 & $(95.45 \%)$ & 16 & $(69.56 \%)$ & 16 & $(76.19 \%)$ \\
\hline Employee Involvement & 13 & $(59.09 \%)$ & $19(82.60 \%)$ & 16 & $(76.19 \%)$ \\
\hline
\end{tabular}

Note: (Green HR Practices followed by more than $60 \%$ of the respondent organizations)

The table 5 shows that $95 \%$ of the respondent manufacturing organizations follow the practice of training in environmental management. The most common green initiative among IT and ITes sector is the communication systems and employee involvement. Green job description is practiced by more than $80 \%$ of the banking and other service sectors. Training in environmental management and green employee involvement are commonly used by the banking and other service sector.

\section{Association between profile of respondent organization and the green human resource practices followed:}

Human resource practices have matured over the years. There has been an effort by organizations to move from being reactive to a proactive approach. Practices initiated by organizations are seen to be sector specific. But, a bird's eye view into the human resource practices shows some similarities on a generic ground. Largely, organizations are seen to adapt to the industry standards. This can be contributed to the fact that each sector has a unique profile of work force to cater to. Thus, human resource practices by large are seen to be sector specific at a micro level. The research paper tries to explore the statistically significant association between the sector to which the respondent belongs and the green human resource initiatives practiced by the respondent organizations. Chi-square test has been administered to find out the statistically significant association between the variables.

\section{Testing of Hypothesis:}

$H_{0}$ : The green job description practices followed by the respondent organizations is independent of the sector to which they belong.

The general job description used by organizations is a human resource practice that orients the employee about the job. Table 6 shows the significance of relationship between the practice and the sector to which the organization belongs. 
Table 6: Chi-Square values of association between sector and green job description practice:

\begin{tabular}{|l|c|c|c|}
\hline \multicolumn{1}{|c|}{ Chi - Square } & $\mathbf{X}^{\mathbf{2}}$ Value & $\begin{array}{c}\text { Degree of } \\
\text { Freedom }\end{array}$ & $\begin{array}{c}\text { Asymp.Sign. } \\
\text { (2- sided) }\end{array}$ \\
\hline Pearson Chi-Square & $15.586^{\mathrm{a}}$ & 2 & .000 \\
\hline Likelihood Ratio & 15.868 & 2 & .000 \\
\hline $\begin{array}{l}\text { Linear-by-Linear } \\
\text { Association }\end{array}$ & 12.926 & 1 & .000 \\
\hline N of Valid Cases & 66 & & \\
\hline
\end{tabular}

a. $O$ cells $(.0 \%)$ have expected count less than 5. The minimum expected count is 8.27.

The table 6 shows that the asymptotic sign in case of job description is not more than 0 . This is not above the significance level of 0.050 . Implying that the green job description practice is not independent of the sector to which the respondent organization belongs. Table 5 in the paper shows that the service sectors like banking, other services, IT and ITES uses general job description to specify a number of environmental aspects. The manufacturing sectors have not yet made an initiative to include special competencies relating to green approach in their job descriptions.
$H_{o}$ The green communication system practices followed by the respondent organizations are independent of the sector to which they belong.

A green communications system in organizations speaks about the extent of adaptation of technology by organizations and employees at large. The cross tabulation between sector and green communication is discussed in table 5 above. Table 7 shows the association between sector and green communication system.

Table7:Chi-Square values of association between sector and green communication system:

\begin{tabular}{|l|c|c|c|}
\hline \multicolumn{1}{|c|}{ Chi - Square } & $\begin{array}{c}\mathbf{X}^{\mathbf{2}} \\
\text { Value }\end{array}$ & $\begin{array}{c}\text { Degree of } \\
\text { Freedom }\end{array}$ & $\begin{array}{c}\text { Asymp.Sign } \\
\text { (2- sided) }\end{array}$ \\
\hline Pearson Chi-Square & $22.623^{\text {a }}$ & 2 & .000 \\
\hline Likelihood Ratio & 24.597 & 2 & .000 \\
\hline Linear-by-Linear Association & 8.855 & 1 & .003 \\
\hline N of Valid Cases & 66 & & \\
\hline
\end{tabular}

O cells $(.0 \%)$ have expected count less than 5 . The minimum expected count is 8.27 
Table 7 shows that the asymptotic sign in case of green communication system is not more than 0 . This is not above the significance level of 0.050 . Hence, implying that the green communication practice is not independent of the sector to which the respondent organization belongs. IT and ITES employees being technology savvy adapt to green communication systems to a large extent, followed by the banking and other service sector. An analysis of table 5 on green communication practices shows that manufacturing sector has yet to catch up with the practices. This is contributed to the profile of workforce constituting the sector.
$H_{0} \quad$ The training in environment management practices followed by the respondent organizations is independent of the sector to which they belong.

The human resource departments of organization initiate training programs for career development, change management and many other people and knowledge relating issues. Table 5 shows that the training imparted relating to waste management and green management is seen to be gaining great momentum in all sectors. Table 8 below shows the association between sector and training practice.

Table 8: Chi-Square values of association between sector and training in environment management:

\begin{tabular}{|l|c|c|c|}
\hline \multicolumn{1}{|c|}{ Chi - Square } & $\mathbf{X}^{2}$ Value & $\begin{array}{c}\text { Degree of } \\
\text { Freedom }\end{array}$ & $\begin{array}{c}\text { Asymp.Sign. } \\
\text { (2- sided) }\end{array}$ \\
\hline Pearson Chi-Square & $5.094^{\mathrm{a}}$ & 2 & .078 \\
\hline Likelihood Ratio & 6.039 & 2 & .049 \\
\hline Linear-by-Linear Association & 2.551 & 1 & .110 \\
\hline N of Valid Cases & 66 & & \\
\hline
\end{tabular}

3 cells (50.0\%) have expected count less than 5. The minimum expected count is 4.14 .

The table 8 shows that the asymptotic sign in case of training in environmental management is 0.78 . This is above the significance level of 0.050 . Implying that the training in environmental management is independent of the sector to which the respondent organization belongs. This signifies that irrespective of the sector, organizations are environmentally conscious. Thus, organizations are seen to be proactive in introducing training programs for employees relating to waste management, transport and air emissions.

$H_{0}$ The green socialization practices followed by the respondent organizations is independent of the sector to which they belong.

Socialization practices are proactive measures that an organization can initiate to bring in the culture of going green. The research paper tries to examine the association of such practices to the sector to which the organization belongs. The cross tabulation between sector and green socialization practice is discussed in table 5 above and table 9 depicts the relationship between the two. 
Table 9: Chi-Square values of association between sector and green socialization practice:

\begin{tabular}{|l|c|c|c|}
\hline \multicolumn{1}{|c|}{ Chi - Square } & $\mathbf{X}^{\mathbf{2}}$ Value & $\begin{array}{c}\text { Degree of } \\
\text { Freedom }\end{array}$ & $\begin{array}{c}\text { Asymp.Sign. } \\
\text { (2- sided) }\end{array}$ \\
\hline Pearson Chi-Square & $2.901^{\mathrm{a}}$ & 2 & .234 \\
\hline Likelihood Ratio & 2.889 & 2 & .236 \\
\hline Linear-by-Linear Association & 1.309 & 1 & .253 \\
\hline $\mathrm{N}$ of Valid Cases & 66 & & \\
\hline
\end{tabular}

a. $O$ cells $(.0 \%)$ have expected count less than 5 . The minimum expected count is 7.64 .

The table 9 shows that the asymptotic sign in case of green socialization practice is 0.234 . This is above the significance level of 0.050 . Hence, implying that the green socialization practice is independent of the sector to which the respondent organization belongs. Sensitizing employees through green socialization practices and making a mark in the society in the green place is a method adopted by all organizations irrespective of the sector. It can be observed here that the IT and ITES sector has marginally higher presence in the practice than other sectors.
$H_{0}$ The green employee involvement practices followed by the respondent organizations is independent of the sector to which they belong.

Employee involvement into green management issues through participative management is seen to be predominantly practices among service organizations as shown in table 5 . Table 10 shows the association between sector and employee involvement practice.

Table 10: Chi-Square values of association between sector and employee involvement:

\begin{tabular}{|l|c|c|c|}
\hline \multicolumn{1}{|c|}{ Chi-Square } & $\mathbf{X}^{\mathbf{2}}$ Value & $\begin{array}{c}\text { Degree of } \\
\text { Freedom }\end{array}$ & $\begin{array}{c}\text { Asymp.Sign. } \\
\text { (2- sided) }\end{array}$ \\
\hline Pearson Chi-Square & $3.322^{\mathrm{a}}$ & 2 & .190 \\
\hline Likelihood Ratio & 3.272 & 2 & .195 \\
\hline Linear-by-Linear Association & 1.605 & 1 & .205 \\
\hline N of Valid Cases & 66 & & \\
\hline
\end{tabular}

a.O cells (.0\%) have expected count less than 5 . The minimum expected count is 5.73 .

The table 10 shows that the asymptotic sign in case of employee involvement in green practice is 0.190 . This is above the significance level of 0.050 . Implying that the employee involvement in green practice is independent of the sector to which the respondent organization belongs. Workers participation in management though a practices widely followed by manufacturing sector has failed to orient its efforts in the direction of involving employees in their environmental management issues. 


\section{Conclusions}

Theoretically there is a plethora of human resource initiatives from recruitment to exit that can be practiced in organisations to gain environmental sustainability. Majority of the respondent organisations provide training to employees relating to environmental management practices. Employee involvement and participation in green suggestion scheme is the practice followed by many respondent organizations. When an analysis was made relating to the age of the organisation and the green human resource practices it was observed that employee involvement and green communication systems were the most practiced. As the study had an almost equal representation from all the sectors a hypothesis was set to test the statistically significant relationship between the practices followed and the sector to which they belong. There is a significant statistical relationship between sector and job description, sector and green communication systems. The manufacturing sector profoundly believes in training their employees relating to issues of environmental practices. The IT and ITES sector and the services sector shows to be sensitive in setting green goals to their employees in their job descriptions.

Employees of the manufacturing organization felt that their organisations were more concerned about safety and quality issues which led to an environmentally sustainable culture. There was no mention about being monetarily rewarded for any green goal accomplishment.

The interviews conducted with employees in the respondent organisations reveals that empioyees are aware of the green human resource initiatives of the organisation. The most prominently mentioned are the training provided by their organisation relating to the initiatives that an individual needs to take relating to saving power and waste management. There were employees who mentioned that they appreciated the initiative of their organization wherein they were asked to submit the emission test report of their vehicle to certify their sensitiveness towards global warming. The employees feel the option of flexible work time contributes to environmental sustainability as, an employee will have the liberty to work only when he is ready and has an interest to work. Telecommute is another initiative that was recognized to be environmental friendly by the employees but, is restricted to only the IT sector.

The employees when going through the process of adapting to the green practices followed by the organisations felt that through the green initiatives their behaviors have changed to a great extent. The employees feel that even outside the work environment they subconsciously have become sensitive towards environmental issues.

\section{Policy Implications}

Participative management relating to the issues of environmental sustainability is to be practiced more in manufacturing organisations. The IT and other service organisations have a practice of suggestion scheme relating to making the organisation environmentally sustainable which has to be replicated by all the organisations as this would also build a culture of social responsiveness in the organisation. Majority of the manufacturing organisations do not set green goals in the job description of their employees, but, setting green goals would facilitate initiating a practice of green behavior 
into the employees thereby facilitating the achievement of environmental sustainability. The manufacturing sector also needs to be more active towards initiating electronic forms of communication. Having a paperless office is the order of the day and also facilitates faster and smoother communication channels. This not only contributes to the environmental issue but also reduces the time and cost of communication. Manufacturing sectors have their factory site and corporate office generally spread over a vast area, introduction of electronic communication would also contribute to the speed and cost of labor. Though there is a lot that has been done in the service sector to create paper less offices, still lot can be done in the space of energy procurement by saving hardware, getting into electronic document management systems and increasing the acceptability of digital signatures. Training is an activity that has maximum adaptation of green initiatives. Incentives can be offered to projects that conduct training in minimum cost and using environmental guidelines. There is a need to look deeply and appreciate the long term returns through green initiatives. The study reveals that organisations are investing in training for environmental issues, but, there is very less emphasis laid on the views of employees who leave the organization. The organisation also needs to make efforts to introduce some legal protection initiatives to whistle blowers relating to the non-green practices of the organisations. As monetary awards are not provided by majority of the respondent organizations towards green initiatives of employees it is understood that such initiatives are to be driven intrinsically. It is an innate behavior that is acquired over the years of growing up through modifications that can be inculcated and does not come due to any interest of materialistic returns.
The future is to see that organisations involve themselves in strategies and plans that make them move ahead into "Going green and saving green". Though there is an option of creating a green enterprise and mastering all the elements of environmentally conscious activity, the organizations at least can seek to drive themselves in this direction.

\section{Directions for future research}

The research has shown that respondent organizations have adopted initiatives that ignite the concern for environmental sustainability. Further the effectiveness of these initiatives and its effects on economic sustainability can be analyzed. Further research can be made in the line of analyzing green behavior of employees as a concept of in role behavior or extra role behavior.

\section{References}

- Bill Roth, (2010) "Interview: Walmart's green human resource initiatives." posted on April $7^{\text {th }}, 2010$, retrieved from http://www.triplepundit.com/2010/04/int erview-walmart-green-human-resourcesbest -practices.com accessed on $23^{\text {rd }}$ June, 2010

- Daily; Bonnie F; Su-Chun Huang, (2001) "Achieving sustainability through attention to human resource factors in environmental management." International Journal of Operations and Production management, Volume 21, Issue 12, page-1539-1552.

- Engelhart, Katie,(2010) "From the bottom up." Canadian Business, 0083100, $5 / 10 / 2010$ volume 83 , issue 7 , Page $-60-61$ business source complete, retrieved from www ebscohost.com accessed on $5^{\text {th }}$ Oct,2010.

- Improving your work (2008) "Environment: 
Is it truly easy being green?." Posted on $9^{\text {th }}$ October, 2008, retrieved from www.evancarmichael.com/ humanresources/773/improving-your-workenvironments accessed on 20th June, 2010.

- Jennifer Schramm, (2008) "Rich, green perspective" HR magazine-future focus, Volume 53, Issue 7, page 112-112 July 2008.

- Jamie Mcmahon, (2009) "Greening your staff." credit union Management, Volume 32, Issue 8, page 22-25, Aug 2009.

- Jaya Sinha, (2010) "Flexible work arrangement: how effective." http:// itvoir.com/portal/boxx/knowledgebase.as p?iid $=821 \&$ Cat $=23$ accessed on 14 th Nov 2010.

- Monica Cavalcanti Sa De Abrev, (2008) "How to define environmental policy to improve corporate sustainability in developing countries." Business Strategy and the Environment, (John Wiley \& Sons Inc) Volume 18, Issue 8, Page 542-556. Aug.2008.

- Manikas, A. M. Godfrey, (2010) "Inducing green behavior in a manufacturer." Global journal of business research. Volume 4 Issue 2 Pages 27-38.

- Nancy Hatch woodward. (2008), “New breed of human resource leader: going green has become a business strategy requiring focused attention." HR Magazine, retrieved from http://findarticles.com/p/ articles/mi_m3495/is 6_53/ai n2788947 4.htm accessed on Nov 14th 2010, published June 2008.

- Nigel P Melvilli, (2010) "Information systems innovation for environmental sustainability." MIS quarterly, Issues and opinions, Volume 34, Issue No.1, March 2010, Page 1-21.
- Oliver Boiral, (2009) "Greening the Corporation through organizational citizenship behaviors." Journal of Business Ethics, Volume 8 Issue 2, Page 221-236.

- Peter A.C. Smith, Carol Sharicz (2011) "The shift needed for sustainability." The learning Organization, Volume 18, Issue 1, Feb 2011, Page 73-86.

- Rimonaczy, Isabel, Pearson, Tony (2010) "Role of $H R$ in the new world of sustainability." Industrial and Commercial Training, Volume 42, Issue 1, Page 11-17.

- Scott Marshall R, Brown Darrell, (2003) "The strategy of sustainability: A systems perspective on environmental initiatives." California Management Review, Volume 46, Issue 1, Page 101-126.

- Singh Mitrabinda (2010) "Indian Business sustainability in the era of Globalization." Advances in Management, Volume 3, Issue 5, May 2010, Page 57-65.

- Susan M. Heathfield (2010) "From a green team to improve your work environment." About.com Guide retrieved from http://humanresources.about.com/od/ employeeinvolvement/ qt/ work environs.htm. accessed on 12th October, 2010.

- Tim Sanders (2009) "How HR can green your company." Employment relations today, Winter, Volume 35 , Issue 4, Page 17-23, Wiley Periodicals Inc.

- Buck Consultants Survey, “Top "Green" Human resource practices target travel and printing". Feb $17^{\text {th }} 2009$, New York (PRWEB), retrieved from www.bucksurveys.com accessed on $11^{\text {th }}$ November, 2010. 